\title{
Restoration of insulin secretion in pancreatic islets of protein-deficient rats by reduced expression of insulin receptor substrate (IRS)-1 and IRS-2
}

\author{
E P Araujo ${ }^{1,2}$, M E C Amaral ${ }^{1}$, E Filiputti ${ }^{1}$, C T de Souza ${ }^{2}$, \\ T L Laurito², V D Augusto", M J A Saad ${ }^{2}$, A C Boschero", \\ L A Velloso ${ }^{2}$ and E M Carneiro ${ }^{1}$ \\ ${ }^{1}$ Department of Physiology and Biophysics, State University of Campinas, Campinas-SP, Brazil \\ ${ }^{2}$ Department of Internal Medicine, FCM - State University of Campinas (UNICAMP), 13083-970, Campinas-SP, Brazil \\ (Requests for offprints should be addressed to L A Velloso; Email: lavelloso@fcm.unicamp.br) \\ (L A Velloso and E M Carneiro participated equally as supervisors for these studies)
}

\begin{abstract}
Autocrine and paracrine insulin signaling may participate in the fine control of insulin secretion. In the present study, tissue distribution and protein amounts of the insulin receptor and its major substrates, insulin receptor substrate (IRS)-1 and IRS-2, were evaluated in a model of impaired glucose-induced insulin secretion, the proteindeficient rat. Immunoblot and RT-PCR studies showed that the insulin receptor and IRS-2 expression are increased, whilst IRS-1 protein and mRNA contents are decreased in pancreatic islets of protein-deficient rats. Immunohistochemical studies revealed that the insulin receptor and IRS-1 and -2 are present in the great majority of islet cells; however, the greatest staining was localized at the periphery, suggesting a co-localization with non-insulin-secreting cells. Exogenous insulin stimulation of isolated islets promoted higher insulin receptor
\end{abstract}

and IRS-1 and -2 tyrosine phosphorylation in islets from protein-deficient rats, as compared with controls. Moreover, insulin-induced IRS-1- and IRS-2-associated phosphatidylinositol 3-kinase activity are increased in islets of protein-deficient rats. The reduction of IRS-1 and IRS-2 protein expression in islets isolated from proteindeficient rats by the use of antisense IRS-1 or IRS-2 phosphorthioate-modified oligonucleotides partially restored glucose-induced insulin secretion. Thus, the impairment of insulin cell signaling through members of the IRS family of proteins in isolated rat pancreatic islets improves glucose-induced insulin secretion. The present data reinforced the role of insulin paracrine and autocrine signaling in the control of its own secretion.

Journal of Endocrinology (2004) 181, 25-38

\section{Introduction}

Type 2 diabetes is a multifactorial metabolic disease with rapidly increasing prevalence in most countries of the world (Zimmet et al. 2001). Genetic and environmental factors play decisive roles in the pathogenesis of the disease (Bell \& Polonsky 2001, Zimmet et al. 2001). In several patients with type 2 diabetes, there is an initial peripheral resistance to insulin, which may be compensated for some time by $\beta$-cell hyperplasia and/or hyper-function (Bell \& Polonsky 2001, Saltiel \& Kahn 2001). As long as the pancreas is able to maintain a sufficient production of insulin, diabetes may not develop. However, upon failure of $\beta$-cell function, which may occur due to the cell's own incapacity to sustain high hormone production, or to a continuously increasing peripheral need for insulin, diabetes will ensue.
Following the demonstration of the presence of the insulin receptor (IR) and its main substrates, insulin receptor substrate (IRS)-1 and IRS-2 in pancreatic islets (Velloso et al. 1995), several reports have provided evidence for the participation of insulin and insulin-like growth factor-I (IGF-I) signaling in islet growth and insulin secretion (Aspinwall et al. 1999, Withers et al. 1999, Xu et al. 1999). IGF-I, acting through IRS-2, may co-ordinate islet growth during late embryogenesis and early postnatal life, and provide a de novo stimulus for growth in case of an extra demand for insulin during adult life, for example as a consequence of peripheral insulin resistance (Withers et al. 1999). In addition, IRS-2 may be operated by insulin inputs or metabolite-dependent signals, and influence the rate and amount of insulin secretion (Withers et al. 1998, 1999, Zhang et al. 1998, Lingohr et al. 2002). Conversely, IRS-1, acting mostly as a 
substrate for the IR, may co-ordinate the islet response to autocrine insulin signaling and its linkage to the glucosegenerated signal, which apparently provides a stimulus for enhanced insulin secretion, and depends on cytosolic $\mathrm{Ca}^{2+}$ accumulation ( $\mathrm{Xu}$ et al. 1999, Aspinwall et al. 2000). Targeted disruption of the IRS-1 gene in the whole body of mice provokes growth retardation accompanied by pancreatic islet hyperplasia and increased insulin secretion (Araki et al. 1994, Kulkarni et al. 1999b). In contrast, IRS-2 whole-body knockout leads to severe insulin resistance, $\beta$-cell hypoplasia with decreased insulin secretion, and early onset diabetes (Kubota et al. 2000). It is possible that the same molecular defects in the insulin signaling pathway, which participate in the mechanisms of peripheral insulin resistance, produce functional modulation of pancreatic islets and, thus, play a role in defective compensation for the continuous demand for insulin, as occurs in incipient diabetes.

Protein malnutrition is associated with a defect in the secretion of insulin by pancreatic $\beta$-cells and with a variable degree of improved insulin sensitivity in peripheral tissues that are, in general, reciprocally counterbalanced to maintain glucose homeostasis (Reis et al. 1997). In humans exposed to low protein diets and in animal models of protein malnutrition, a subsequent prolonged period of hyper-feeding may provoke imbalance in the glucose equilibrium, leading to diabetes or glucose intolerance (Hales \& Barker 2001). Since it has been observed that treatment of isolated pancreatic islets of Wistar rats, fed with standard chow, with a phosphorthioate-modified antisense oligonucleotide directed against IRS-1 promoted a significant increase in glucose-induced insulin secretion (Araujo et al. 2002), we decided to test if the same approach would lead to an improved functional response of the insulin secretiondefective pancreatic islets of protein-deficient rats. Moreover, we evaluated the participation of IRS-2 in the control of basal and glucose-induced insulin secretion of pancreatic islets of control and protein-deficient rats.

\section{Materials and Methods}

\section{Antibodies, chemicals and buffers}

Antibodies against IR $\beta$ (SC-711), IRS-1 (SC-560), IRS-2 (SC-9299) and somatostatin (SC-7819) were from Santa Cruz Biotechnology (Santa Cruz, CA, USA). Antibodies against rat insulin (guinea pig raised) were kindly donated by Dr Leclerq-Meyer (Free University, Brussels, Belgium). Antibodies against phosphotyrosine (no. 05-321) were from UBI (Lake Placid, NY, USA). Somatostatin and glucagon RIA kits were from Phoenix Pharmaceuticals, Inc. (Belmont, CA, USA) and Linco Research Inc. (St Charles, MI, USA) respectively; insulin was determined by RIA. ${ }^{125}$ I-Protein A Sepharose and ${ }^{125}$ I-insulin were from Amersham International plc (Amersham, Bucks,
Table 1 Composition of control (17\% protein) and low protein $(6 \%$ protein) diets (Reeves et al. 1993)

\begin{tabular}{|c|c|c|}
\hline \multirow[b]{3}{*}{ Ingredient } & \multicolumn{2}{|c|}{ Composition (g/kg) } \\
\hline & Control & Low protein \\
\hline & & \\
\hline Casein & $202 \cdot 0$ & $71 \cdot 5$ \\
\hline Cornstarch & $397 \cdot 5$ & $480 \cdot 0$ \\
\hline Sucrose & $100 \cdot 0$ & $121 \cdot 0$ \\
\hline Fiber & $50 \cdot 0$ & $50 \cdot 0$ \\
\hline Dextrinized cornstarch & $130 \cdot 0$ & $159 \cdot 0$ \\
\hline L-cystein & $3 \cdot 0$ & $1 \cdot 0$ \\
\hline Soybean oil & $70 \cdot 0$ & $70 \cdot 0$ \\
\hline Mineral mix (AIN-93G-MX) & $35 \cdot 0$ & $35 \cdot 0$ \\
\hline Vitamin mix (AIN-93-VX) & $10 \cdot 0$ & $10 \cdot 0$ \\
\hline Choline chlorhydrate & $2 \cdot 5$ & $2 \cdot 5$ \\
\hline
\end{tabular}

UK). Protein A Sepharose $6 \mathrm{MB}$ was from Pharmacia (Uppsala, Sweden). All the remaining chemicals used in the experiments were from Sigma (St Louis, MO, USA). Buffer A used in immunoblotting experiments consisted of $100 \mathrm{mM}$ Tris, $10 \mathrm{~g} / 1$ SDS, $50 \mathrm{mM}$ HEPES (pH 7•4), $100 \mathrm{mM}$ sodium pyrophosphate, $100 \mathrm{mM}$ sodium fluoride, $10 \mathrm{mM}$ EDTA, $10 \mathrm{mM}$ sodium vanadate, $2 \mathrm{mM}$ phenylmethylsulfonyl fluoride and $0 \cdot 1 \mathrm{mg} / \mathrm{ml}$ aprotinin.

\section{Phosphorthioate-modified oligonucleotides}

Sense and antisense phosphorthioate oligonucleotides specific for IRS-1 (sense, $5^{\prime}$ ACC CAC TCC TAT CCC G $3^{\prime}$ and antisense, 5' CGG GAT AGG AGT GGG T $3^{\prime}$ ) and IRS-2 (sense, $5^{\prime}$ GGA GGC GGC TAC AAA G $3^{\prime}$ and antisense, 5' CTT TGT AGC CGC CTC C 3') were produced by Invitrogen Corp. (Carlsbad, CA, USA). Both sequences were selected among three unrelated pairs of oligonucleotides on the basis of their ability to block IRS-1 and IRS-2 protein expression respectively, as evaluated by immunoblot of total protein extracts of isolated pancreatic islets utilizing specific anti-IRS-1 or anti-IRS-2 antibodies. The antisense oligonucleotide sequences were submitted to BLAST analyses (at www.ncbi.nlm.nih.gov) and matched only for the Rattus norvegicus IRS-1 or IRS-2 coding sequences respectively.

\section{Experimental animals and islet isolation}

All experiments were performed with male Wistar rats from the University of Campinas Breeding Center. At 28 days of age, the rats were randomly distributed into two groups, a control group that received standard rodent chow containing $17 \%$ protein and a protein-deficient group that received an isocaloric chow containing $6 \%$ protein (Table 1) for 12 weeks. For islet isolation, the rats were anesthetized by intraperitoneal injection of sodium amobarbital (15 mg/kg body weight) and, following the loss of corneal 
and pedal reflexes, the animals were killed by decapitation. Abdominal cavities were rapidly opened and the pancreatic duct was cannulated for collagenase infusion. The pancreas was then removed and submitted to collagenase digestion. Islets were isolated by careful handpicking, following a method previously described (Bjork et al. 1994). The University of Campinas Ethical Committee approved all experiments.

\section{Immunohistochemistry}

Pancreata obtained from three rats of each experimental group were examined to determine the expression and tissue distribution of proteins that participate in insulin signaling. Hydrated, $5 \mu \mathrm{m}$ sections of paraformaldehydefixed, paraffin-embedded tissue were stained by the avidin-peroxidase and single-staining fluorescence methods. Sections were incubated for $30 \mathrm{~min}$ with $2 \%$ normal rabbit or normal goat sera at room temperature, and then exposed for $12 \mathrm{~h}$ in a moister chamber at $4{ }^{\circ} \mathrm{C}$ to the primary antibodies against IR $\beta(1 / 20)$, IRS- $1(1 / 50)$, IRS-2 $(1 / 50)$ or somatostatin $(1 / 20)$. For the avidinperoxidase method, biotinylated secondary antibodies were used in incubations for $2 \mathrm{~h}$ at room temperature, followed by a 1-h incubation with ready-to-use avidincoupled peroxidase from Vector (Burlingame, CA, USA). The resulting immunocomplexes were detected with $50 \mathrm{mg} / 100 \mathrm{ml}$ diaminobenzidine $-4 \mathrm{M} \mathrm{HCl} / 0 \cdot 01 \mathrm{ml} /$ $100 \mathrm{ml} \mathrm{H}_{2} \mathrm{O}_{2}$ dissolved in $5 \mathrm{mM}$ Tris, $\mathrm{pH}$ 7·6. For single immunofluorescence staining, fluorescein isothiocyanate (FITC)-conjugated secondary antibodies were employed. Analysis and photo-documentation were performed using an Olympus BX60 microscope and a Zeiss LSM 510 laser scanning confocal microscope.

\section{Static secretion studies}

One hundred groups of freshly isolated islets were initially incubated for $6 \mathrm{~h}$ at $37^{\circ} \mathrm{C}$, in RPMI (Life Technologies, Gaithersburg, MD, USA) containing $2.8 \mathrm{mM}$ glucose with no oligonucleotide or in the presence of either $4 \mathrm{nmol}$ (in $10 \mathrm{ml}$ RPMI) sense or $4 \mathrm{nmol}$ antisense IRS-1 or IRS-2 oligonucleotides. RPMI was then replaced and islets were maintained for $3 \mathrm{~h}$ (for insulin measurement) or $90 \mathrm{~min}$ (for glucagon and somatostatin measurement) under the experimental conditions (RPMI containing $2.8 \mathrm{mM}$ or $16.7 \mathrm{mM}$ glucose, with either no oligonucleotide addition or in the presence of sense or antisense oligonucleotides). At the end of the incubation time, samples of the supernatants of the incubation medium were collected for hormone (insulin, glucagon and somatostatin) measurement.

\section{Dynamic insulin secretion studies}

Groups of 100 freshly isolated islets were preincubated for $6 \mathrm{~h}$ at $37^{\circ} \mathrm{C}$ in RPMI containing $2.8 \mathrm{mM}$ glucose with no oligonucleotide or in the presence of either $4 \mathrm{nmol}$ (in $10 \mathrm{ml} \mathrm{RPMI}$ ) sense or $4 \mathrm{nmol}$ antisense IRS-1 or IRS-2 oligonucleotides. Thereafter, the islets were placed on a Millipore SW 1300 filter $(8 \mu \mathrm{m}$ pore) in a perifusion chamber. Islets were continuously perfused at a flow rate of $1 \mathrm{ml} / \mathrm{min}$. During the initial $20 \mathrm{~min}$ of perifusion, the buffer consisted of Krebs-bicarbonate solution containing $2.8 \mathrm{mM}$ glucose (when required, oligonucleotides at the concentration of $0.4 \mathrm{mM}$ were maintained in the perifusate). Finally, perifusion buffer containing $16.7 \mathrm{mM}$ glucose was introduced. Samples of perifusate for quantification of insulin were collected every second minute starting at the tenth minute after the onset of perifusion.

\section{Immunoblot, immunoprecipitation and phosphatidylinositol 3-kinase (PI3-kinase) activity analysis}

For specific protein determination, groups of 300 freshly isolated islets were incubated for $6 \mathrm{~h}$ in RPMI containing $2.8 \mathrm{mM}$ glucose in the presence of $4 \mathrm{nmol}$ (in $10 \mathrm{ml}$ RPMI) sense or antisense IRS-1 or IRS-2 oligonucleotides or with no addition of oligonucleotide. Following incubation, islets were lysed in $0.3 \mathrm{ml}$ boiling buffer $\mathrm{A}$ and insoluble material was removed by centrifugation for $20 \mathrm{~min}$ at $8000 \mathrm{~g}$. Protein quantification in the supernatants was determined by the Bradford (1976) method. Samples containing $0.2 \mathrm{mg}$ total proteins were separated by SDS-PAGE, transferred to nitrocellulose membranes and blotted with specific antibodies. For immunoprecipitation followed by immunoblot analysis and for IRS-1and IRS-2-associated PI3-kinase activity assays, groups of 800 pancreatic islets were exposed to experimental conditions and technical procedures were performed as previously described (Velloso et al. 1996, Luciano et al. 2002). Visualization of specific protein bands was performed by incubating membranes with ${ }^{125}$ I-protein A followed by exposure to RX films (Kodak). For phosphoinositol phosphate (PIP) evaluation in PI3-kinase assays, thin layer chromatography (TLC) plates were exposed to RX films.

Semi-quantitative analysis of IRS-1, IRS-2 and somatostatin $m R N A$

Groups of islets were cultured for $12 \mathrm{~h}$ at $37^{\circ} \mathrm{C}$ in RPMI 1640 medium containing $5.6 \mathrm{mM}$ glucose and $5 \%$ fetal calf serum. Sense or antisense IRS-1 phosphorthioatemodified oligonucleotide were added as required following the same doses and protocol as described. To determine the expression level of IRS-1, IRS-2 and somatostatin mRNA, the relative amount of respective products obtained by RT-PCR was compared with external control potato virus $\mathrm{X}$ (PVX) or $\beta$-actin mRNA. Total cellular RNA was extracted from groups of 500 islets using Trizol reagent (Invitrogen, Carlsbad, CA, USA). Reverse transcription was performed on $1 \mu \mathrm{g}$ total RNA using 
Moloney murine leukemia virus-reverse transcriptase (Superscript II) and random hexamers according to the manufacturer's instructions (Invitrogen). RT-PCR assays were performed using Taq DNA polymerase, recombinant (Invitrogen) containing $10 \mathrm{pmol}$ of each primer in a master mix of $50 \mu \mathrm{l}$. PCR primers for rat somatostatin (forward, 5' ACC GGG AAA CAG GAA CTG GC 3'; reverse, 5' TGG GAT TTG GAG GAG AGG GAT C 3') amplify a $277 \mathrm{bp}$ cDNA fragment, and for rat $\beta$-actin (forward, 5' ATG AAG ATC CTG ACC GAG CGT G 3'; reverse, 5' CTT GCT GAT CCA CAT CTG CTG G $3^{\prime}$ ) amplify a 510 bp cDNA fragment. PCR amplification conditions were $2 \mathrm{~min}$ at $95^{\circ} \mathrm{C}$ followed by cycles of $95{ }^{\circ} \mathrm{C}$ for $30 \mathrm{~s}, 58^{\circ} \mathrm{C}$ for $30 \mathrm{~s}$, and $72{ }^{\circ} \mathrm{C}$ for $30 \mathrm{~s}$. The number of cycles was 26 for $\beta$-actin and 32 for somatostatin. PCR primers for rat IRS-1 (forward, $5^{\prime}$ ACC CAC TCC TAT CCC G $3^{\prime}$; reverse, $5^{\prime}$ CCC TAC TCC GTT TGT CC $3^{\prime}$ ) amplify a 375 bp cDNA fragment, for rat IRS-2 (forward, 5' AGC TGG TGG TAG TCA TAC CC 3'; reverse, 5' CAG GTT CAT ATA GTC AGA 3') amplify a 390 bp cDNA fragment, and for PVX (forward, 5' CCT GCT CTA CGG ACT TAT C 3'; reverse, 5' GTA GTT GAG GTA GTT GAC CC 3') amplify a $125 \mathrm{bp}$ cDNA fragment. PCR amplification conditions were $2 \mathrm{~min}$ at $94{ }^{\circ} \mathrm{C}$ followed by cycles of $94{ }^{\circ} \mathrm{C}$ for $30 \mathrm{~s}$, $54{ }^{\circ} \mathrm{C}$ for $30 \mathrm{~s}$, and $72{ }^{\circ} \mathrm{C}$ for $30 \mathrm{~s}$. The number of cycles was 37 for PVX, 32 for IRS-1 and 34 for IRS-2. Cycle numbers were defined after titration between 20 and 42 cycles and were within the logarithmic phase of amplification. PCR samples were submitted to electrophoresis on a $2 \%$ agarose gel, and DNA was visualized by ethidium bromide staining. The band intensities were determined by digital scanning, followed by quantification using Scion Image analysis software.

\section{Statistical analysis}

Specific protein or cDNA bands present on the blots or on the agarose gels respectively, or PIP dots on TLC plates were quantified by densitometry. Mean values \pm S.E.M. obtained from densitometric scans, and values for insulin and glucagon during static secretion studies were compared utilizing the Turkey-Kramer test (ANOVA). Insulin quantification during dynamic secretion studies was compared after log transformation in order to correct for variance heterogeneity or non-normality utilizing the Turkey-Kramer test (ANOVA). A $P<0 \cdot 05$ was accepted as statistically significant.

\section{Results}

Characteristics of the protein-deficient rat

After 12 weeks of treatment, there were significant differences between the control and protein-deficient rats in total body weight ( $274 \pm 38$ vs $152 \pm 22$ g respectively, $n=12, P<0 \cdot 05)$, liver glycogen concentration $(0 \cdot 68 \pm$ 0.21 vs $1.38 \pm 0.37 \mathrm{mg} / 100 \mathrm{~g}$ respectively, $n=6, \quad P<$ $0 \cdot 05)$, total serum albumin $(35 \cdot 2 \pm 0 \cdot 5$ vs $32 \cdot 1 \pm 0 \cdot 05 \mathrm{~g} / 1$ respectively, $n=6, P<0.05)$ and fasting insulin level $(175 \pm 31$ vs $119 \pm 18 \mathrm{pmol} / 1$ respectively, $n=6, \quad P<$ $0 \cdot 05)$. No significant difference was detected in daily food ingestion, fasting glucose concentration and plasma free fatty acids.

Immunohistochemical characterization of IR, IRS-1 and $I R S-2$ expression in pancreatic islets of protein-deficient rats

Using specific polyclonal antisera against IR, IRS-1 and IRS-2, it was demonstrated that all three proteins that participate in insulin signal transduction are expressed in most cells of the pancreatic islets, in control and in protein-deficient rats (Fig. 1). The highest expression of IR, IRS-1 and IRS-2 occurred in cells at the periphery of the islets, according to the pattern of staining obtained in three independent experiments, and based on the evaluation of at least ten islets per histological section. Comparative evaluation of the pattern of staining suggested that pancreatic islets of protein-deficient rats expressed higher protein levels of IR and IRS-2, and lower protein levels of IRS-1 than control rats.

Immunoblot evaluation of IR, IRS-1 and IRS-2 protein expression and RT-PCR evaluation of IRS- 1 and IRS-2 $m R N A$ levels in pancreatic islets of protein-deficient rats

As depicted in Fig. 2, pancreatic islets of protein-deficient rats expressed higher quantities of IR $(\sim 150 \%, P<0 \cdot 05$, Fig. 2a) and IRS-2 ( $160 \%, P<0 \cdot 05$, Fig. $2 c)$ and a lower quantity of IRS-1 $(\sim 60 \%, P<0 \cdot 05$, Fig. $2 b)$ than pancreatic islets of control rats. The results for IRS-1 and IRS-2 were further confirmed by evaluation of mRNA levels by RT-PCR, which showed a significantly lower level of IRS-1 $(\sim 50 \%, P<0 \cdot 05$, Fig. 2 d) and a significantly higher level of IRS-2 $(\sim 170 \%, P<0 \cdot 05$, Fig. $2 \mathrm{e})$ in pancreatic islets of protein-deficient rats.

Insulin-induced IR, IRS-1 and IRS-2 tyrosine phosphorylation, and IRS-1/IRS-2-associated PI3-kinase activity in pancreatic islets of protein-deficient rats

To evaluate the ability of exogenous insulin to induce molecular activation of IR, IRS-1 and IRS-2, and the IRS-1/IRS-2-associated PI3-kinase activity, groups of 800 islets were incubated in the presence of $2.8 \mathrm{mM}$ glucose and challenged, or not, for 2 min with exogenous insulin $\left(10^{-7} \mathrm{M}\right)$. As shown in Fig. 3a, b and c respectively, insulin induced significantly higher tyrosine phosphorylation levels of IR $(\sim 140 \%, P<0 \cdot 05)$, IRS-1 $(\sim 140 \%, P<0 \cdot 05)$ and IRS-2 $(\sim 140 \%, P<0 \cdot 05)$ in 


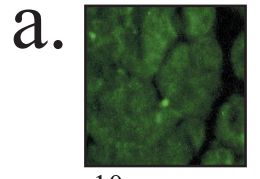

$10 \mu \mathrm{m}$

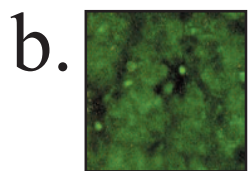

$10 \mu \mathrm{m}$

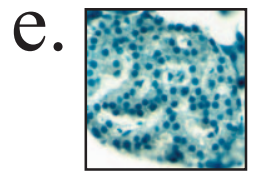

$10 \mu \mathrm{m}$

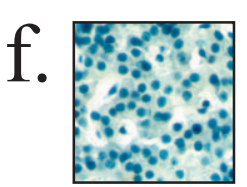

$10 \mu \mathrm{m}$

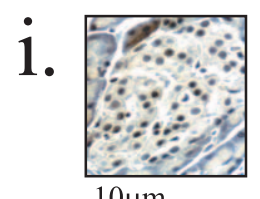

$10 \mu \mathrm{m}$

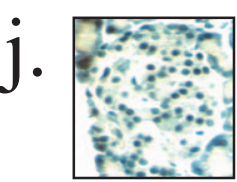

$10 \mu \mathrm{m}$

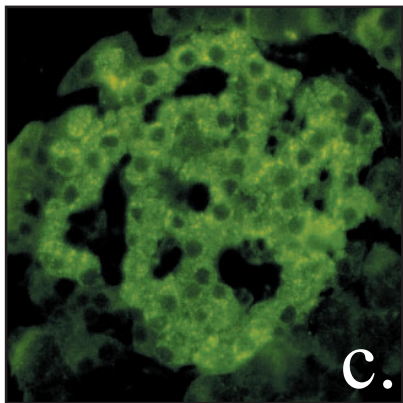

$10 \mu \mathrm{m}$

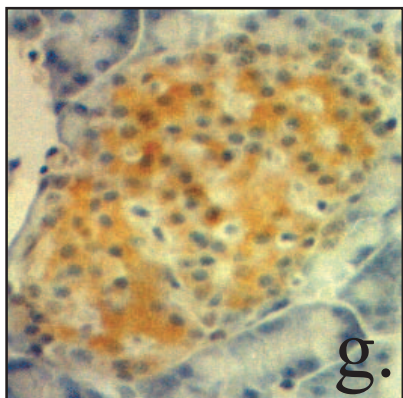

$10 \mu \mathrm{m}$

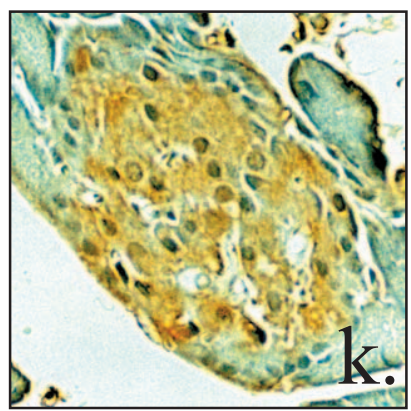

$10 \mu \mathrm{m}$

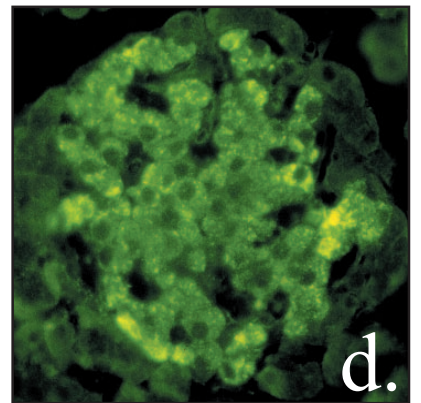

$10 \mu \mathrm{m}$

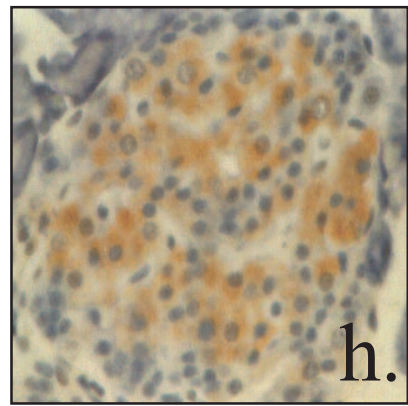

$10 \mu \mathrm{m}$

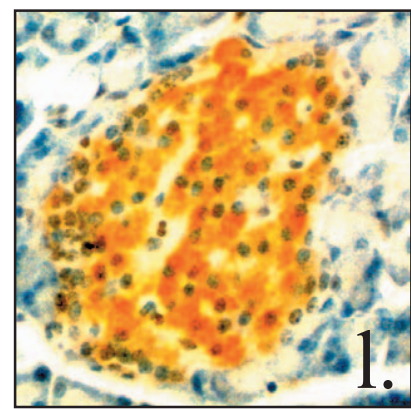

$10 \mu \mathrm{m}$

Figure 1 Immunohistochemical characterization of IR (a-d), IRS-1 (e-h) and IRS-2 (i-I) in pancreatic islets of Wistar rats fed regular chow $(a, c, e, g, i$ and $k)$ and protein-deficient Wistar rats $(b, d, f, h, j$ and $I)$. Sections $(5 \mu m)$ of paraformaldehyde-fixed, paraffin-embedded pancreata of rats were stained using IR $(\mathrm{c}-\mathrm{d})$, IRS-1 $(\mathrm{g}-\mathrm{h})$ or IRS-2 $(\mathrm{k}-\mathrm{I})$ primary antibodies and

FITC-coupled secondary antibody (c-d), or biotinylated secondary antibody followed by treatment with avidin coupled to peroxidase $(\mathrm{g}-\mathrm{h}$ and $\mathrm{k}-\mathrm{l})$. Signal detection and image acquisition were performed in fluorescence $(\mathrm{a}-\mathrm{d})$ or optical $(\mathrm{e}-\mathrm{l})$ microscopes. Methodological controls were exposed to species-specific pre-immune sera ( $a-b, e-f$ and $\mathrm{I}-\mathrm{j})$. Photographs are representative of three distinct experiments.

pancreatic islets of protein-deficient rats as compared with control. In subsequent experiments, $2 \mathrm{mg}$ protein from samples prepared as above were used in immunoprecipitation protocols with anti-IRS-1 or anti-IRS-2 antibodies. Immunocomplexes were recovered with protein A Sepharose and evaluated for associated PI3- kinase activity. As shown in Fig. 3d and e respectively, higher insulin-induced IRS-1-associated PI3-kinase activity $(\sim 140 \%, P<0 \cdot 05)$ and higher IRS-2-associated PI3-kinase activity $(\sim 140 \%, P<0 \cdot 05)$ were encountered in pancreatic islets of protein-deficient rats, as compared with control. 
a.

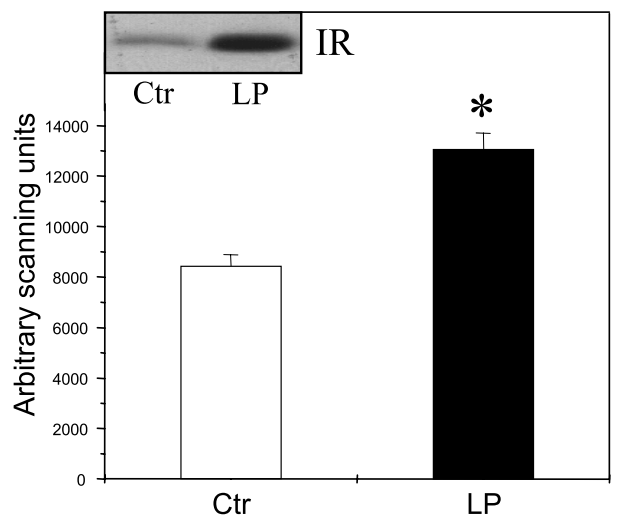

c.

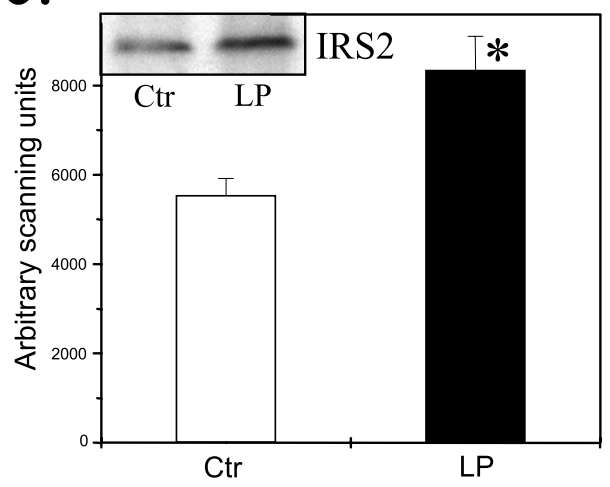

e.

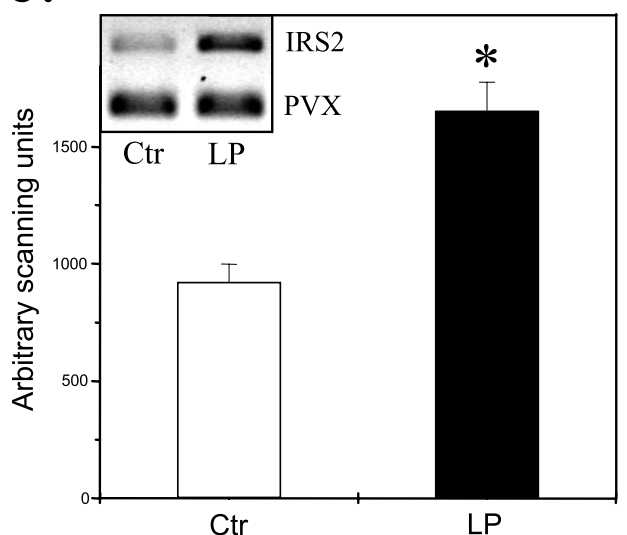

b.

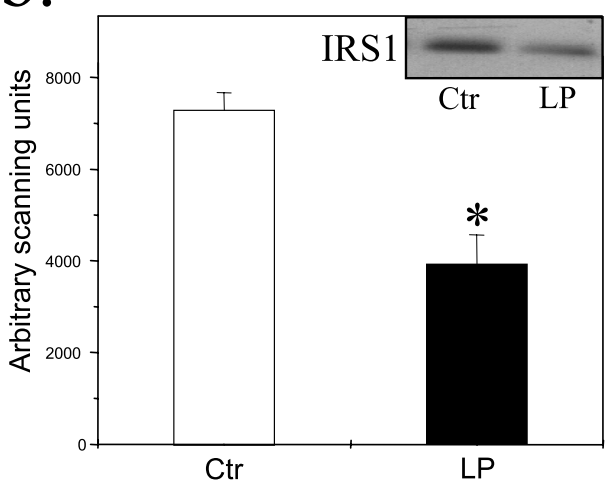

d.

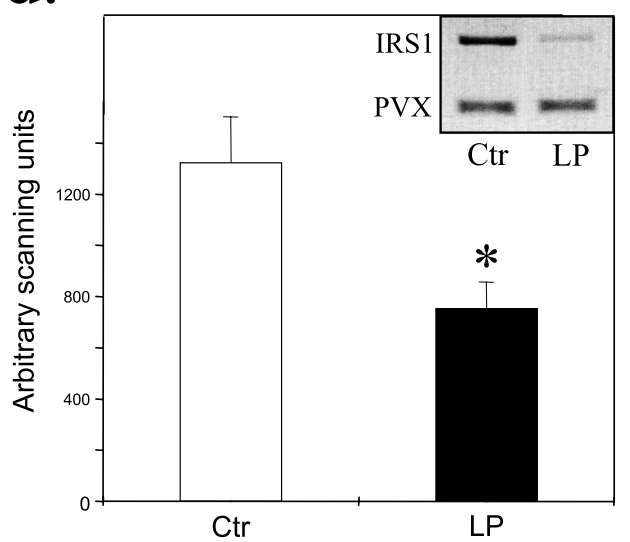

Figure 2 IR, IRS-1 and IRS-2 expression in pancreatic islets of Wistar rats fed regular (Ctr) or proteindeficient (LP) chow. Protein extracts $(0 \cdot 2 \mathrm{mg}$ total protein) obtained from control and protein-deficient rats were separated by SDS-PAGE, transferred to nitrocellulose membranes and blotted with anti-IR (a), -IRS-1 (b) or -IRS-2 antibodies (c). IRS-1 and IRS-2 mRNAs expression were determined by RT-PCR ( $\mathrm{d}$ and e respectively) in pancreatic islets of control and protein-deficient rats. mRNA quantifications were performed in parallel with internal control PVX. In all experiments, $n=6$ and ${ }^{*} P<0.05$ vs Ctr. Values are means \pm S.E.M. 
a.

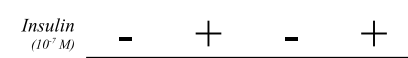

IP: IR/IB: $\mathrm{pY}$

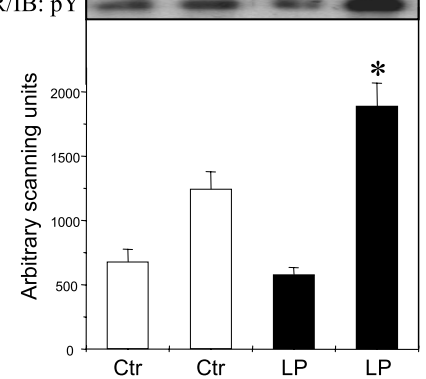

C.

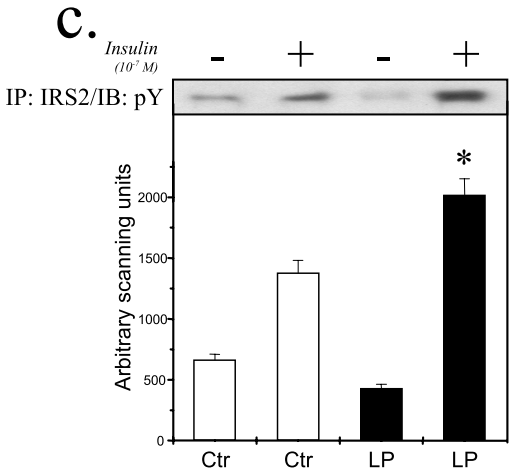

e.

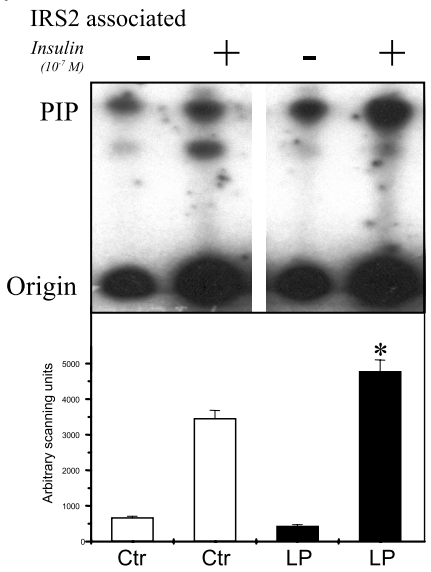

b.

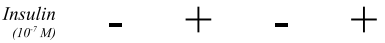

IP: IRS1/IB: pY

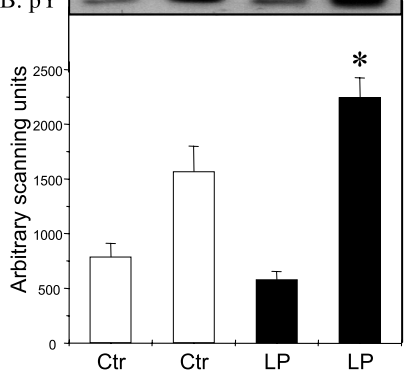

d.

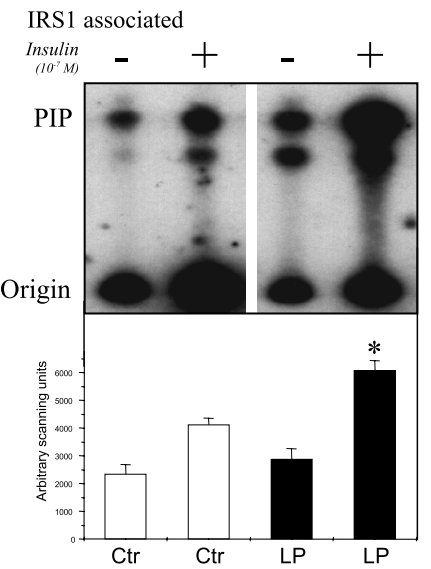

Figure 3 Insulin-induced tyrosine phosphorylation of IR (a), IRS-1 (b) and IRS-2 (c), and IRS-1- (d) or IRS-2 (e) -associated PI3-kinase activity in pancreatic islets of control (Ctr) and protein-deficient Wistar rats (LP). Samples containing $0.5 \mathrm{mg}(\mathrm{a}-\mathrm{c})$ or $2.0 \mathrm{mg}(\mathrm{d}-\mathrm{e})$ total protein obtained from pancreatic islets of control or protein-deficient rats and treated (+) or not (-) with $10^{-7} \mathrm{M}$ insulin were submitted to immunoprecipitation (IP) with anti-IR (a), anti-IRS-1 (b and d) or IRS-2 (c and e) antibodies. Immunoprecipitated proteins were separated by SDS-PAGE $(\mathrm{a}-\mathrm{C})$, transferred to nitrocellulose membranes and blotted (IB) with anti-phosphotyrosine $(\mathrm{pY})$ antibodies, or utilized for determination of PI3-kinase activity ( $\mathrm{d}-\mathrm{e})$, according to the method described in Materials and Methods, and resolved by TLC. In all experiments $n=6$ and ${ }^{*} P<0.05$ vs Ctr + . Values are means \pm S.E.M. 
Effect of the reduction of pancreatic islet IRS-1 and IRS-2 expression upon insulin secretion

To determine the role of IRS-1 and IRS-2 signaling upon insulin secretion, pancreatic islets were incubated in the presence of phosphorthioate-modified IRS-1 or IRS-2 antisense oligonucleotide (and respective controls, sense and with no addition of oligonucleotide) and evaluated for basal and glucose-stimulated insulin secretion in static and dynamic secretion protocols. Initially the effect of IRS-1 antisense oligonucleotide treatment upon IRS-1 protein expression was evaluated by immunoblot. As shown in Fig. 4a, oligonucleotide antisense treatment led to a significant reduction in IRS-1 expression in pancreatic islets of control $(\sim 35 \%, P<0.05)$ and protein-deficient rats $(\sim 45 \%, P<0 \cdot 05)$. No effect was detected with sense oligonucleotide treatment. During static insulin secretion studies (Fig. 4b and c), the reduction of IRS-1 expression provoked an increase in basal $(\sim 170 \%, P<0.05)$ and glucose-stimulated $(\sim 180 \%, P<0 \cdot 05)$ insulin secretion in islets from protein-deficient rats. The same treatment led to an increase in glucose-induced ( $\sim 210 \%, P<0.05)$, but not basal, insulin secretion from pancreatic islets of control rats. In addition, a significant increase in the insulinsecretion rate was observed during the high glucose perifusion phase, both in islets of control $(P<0.05)$ and protein-deficient $(P<0 \cdot 05)$ rats (Fig. $4 \mathrm{~d}$ and e). Interestingly, the greatest difference in insulin secretion rates between islets treated with IRS-1 antisense oligonucleotide and islets incubated with no oligonucleotide occurred in the final samples of the perifusate, suggesting that reduction of IRS-1 expression modulates mostly second phase insulin secretion.

With respect to IRS-2, significant reductions in control $(\sim 40 \%, \quad P<0 \cdot 05)$ and protein-deficient $\quad(\sim 40 \%$, $P<0.05)$ IRS-2 expression were obtained in pancreatic islets treated with IRS-2 antisense oligonucleotide (Fig. $5 a)$. This approach did not produce any significant modulation of basal and glucose-stimulated insulin secretion in islets of control rats (Fig. 5b, c and d). However, the reduction of IRS-2 expression led to a significant increase in glucose-induced insulin secretion from islets from protein-deficient rats, as evaluated in static (Fig. 5c) and dynamic (Fig. 5e) secretion studies.

Effects of reduction of IRS-1 protein expression upon glucagon secretion and somatostatin expression in pancreatic islets of protein-deficient rats

In a previous study, we observed that the reduction of IRS-1 expression in pancreatic islets isolated from Wistar rats fed with regular chow induced modulation of glucagon secretion and somatostatin expression (Araujo et al. 2002). Since the effect of reduction of IRS-1 protein expression upon insulin secretion was more pronounced than the effect of reduction of IRS-2 protein expression we evaluated the role of IRS-1 in the secretion of glucagon and expression of somatostatin in pancreatic islets of protein-deficient rats. For this, groups of 100 islets were incubated in the presence of antisense IRS-1 oligonucleotide (or respective controls, sense and with no addition of oligonucleotide) and exposed to low $(2.8 \mathrm{mM})$ or high $(16.7 \mathrm{mM})$ glucose concentration. Similarly to the control, the reduction of IRS-1 in islets of protein-deficient rats led to a reduction in glucagon secretion from islets exposed to low glucose. However, in contrast to islets not exposed to antisense oligonucleotide, the reduction of IRS-1 expression induced a reversal of the pattern of glucagon secretion in such a way that instead of reducing its secretion in high glucose concentrations, as compared with the low glucose concentrations, an increased glucagon secretion occurred in islets exposed to high glucose (Fig. 6a). Since the amounts of somatostatin secreted by isolated pancreatic islets are below the detectability limit of all RIA kits available, islets of control and protein-deficient rats were incubated in the presence of antisense IRS- 1 oligonucleotide (and respective controls) and, following incubation, total RNA was obtained, reverse transcribed and cDNA was utilized in a semi-quantitative PCR protocol in parallel with an internal control, $\beta$-actin. As shown in Fig. 6b, islets from protein-deficient rats expressed higher levels of somatostatin mRNA than control rats $(\sim 220 \%$, $P<0 \cdot 05)$. This finding was further supported by immunostaining of pancreatic islets of control and proteindeficient rats with anti-somatostatin primary antibody (Fig. 6c-e), which clearly showed, in all islets evaluated (three pancreata from each condition, ten islets evaluated per section), that higher levels of somatostatin are present in islets of protein-deficient rats. Finally, the reduction of IRS-1 expression in pancreatic islets of protein-deficient rats leads to a significant reduction in somatostatin mRNA expression $(\sim 60 \%, P<0.05$ vs low protein-treated with no oligonucleotide) (Fig. 6b), similar to the effect of IRS-1 expression impairment in islets of control rats (Araujo et al. 2002).

\section{Discussion}

There are several reasons for studying insulin secretion in animal models of protein deficiency. Initially, protein deficiency has been implicated as one of the pathogenic factors involved in malnutrition-related diabetes, a rare type of diabetes that may occur in malnourished patients from tropical, developing countries (Abu-Bakare et al. 1986, Rao 1988). Secondly, according to the theory of the thrifty phenotype, malnutrition during the intra-uterine period, or during early postnatal life, may predispose to development of type 2 diabetes and obesity during adulthood (Hales 1997, Hales \& Barker 2001). In both cases, defective insulin secretion by the pancreatic $\beta$-cell may play a central role in the pathogenesis of these diseases. 
a.

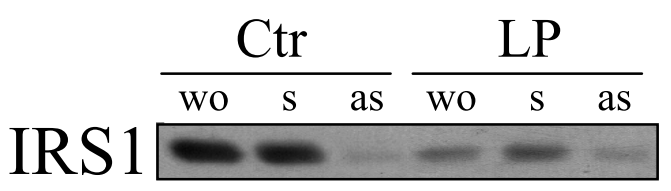

b.

\section{Glucose $2.8 \mathrm{mmol} / \mathrm{l}$}

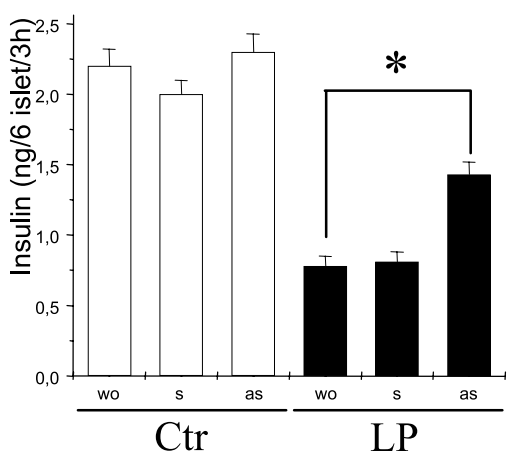

d.

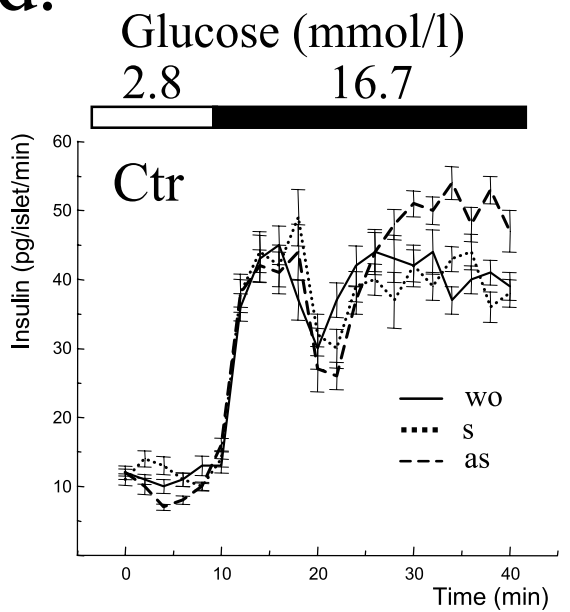

C. Glucose $16.7 \mathrm{mmol} / \mathrm{l}$

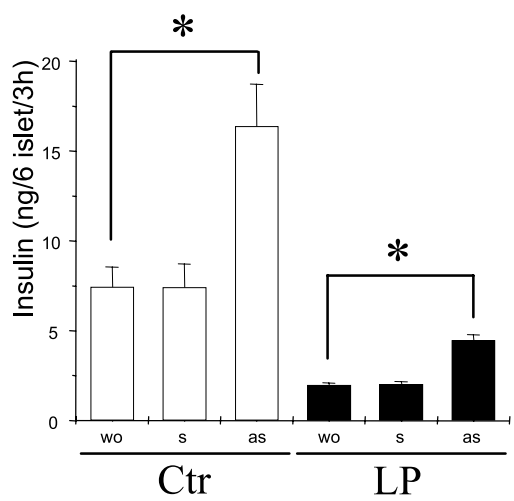

e.

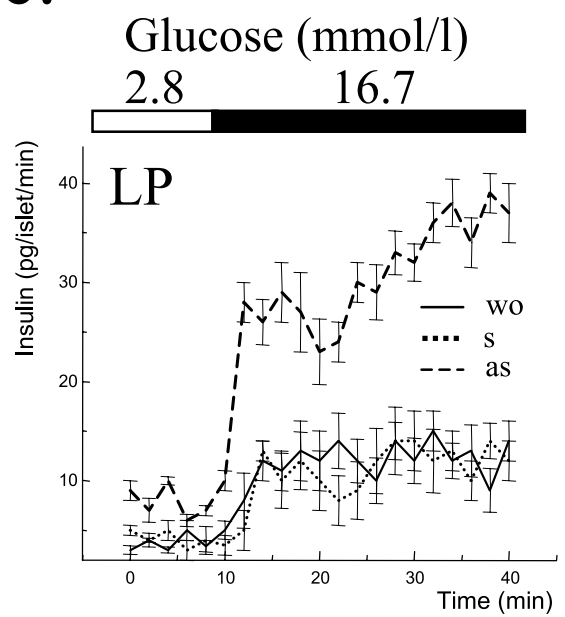

Figure 4 Effects of pancreatic islet IRS-1 protein expression reduction by IRS- 1 phosphorthioate antisense oligonucleotide on static and dynamic insulin secretion by isolated pancreatic islets of control (Ctr) and protein-deficient (LP) rats. Total protein $(200 \mu \mathrm{g})$ from pancreatic islets of control and protein-deficient rats, treated with IRS-1 phosphorthioate antisense (as) or sense (s) oligonucleotide, or not exposed to oligonucleotide (wo), were separated by SDS-PAGE, transferred to nitrocellulose membrane and blotted with anti-IRS-1 antibody (a). Groups of six $(b-c)$ or $100(d-e)$ islets isolated from control or proteindeficient rats and treated with IRS-1 phosphorthioate antisense, sense oligonucleotide, or not exposed to oligonucleotide, were submitted to a protocol for evaluation of static insulin secretion in low $(2.8 \mathrm{mM})$

(b) or high (16.7 mM) (c) glucose concentration, or for evaluation of dynamic insulin secretion (d, control; e, protein-deficient rats), according to the methods described in Materials and Methods. In all experiments $n=6$ and ${ }^{*} P<0 \cdot 05$ vs wo within the experimental group. Values are means \pm S.E.M. 


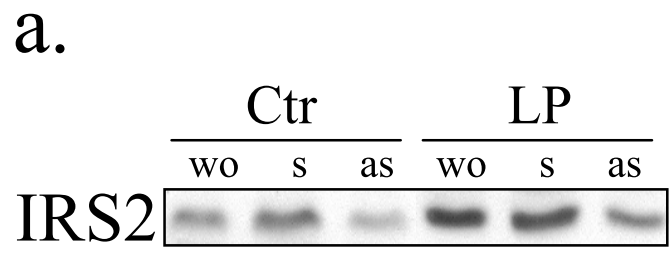

b.

Glucose $2.8 \mathrm{mmol} / \mathrm{l}$

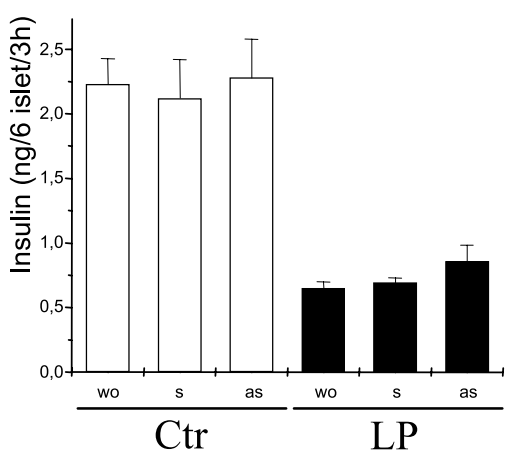

d.

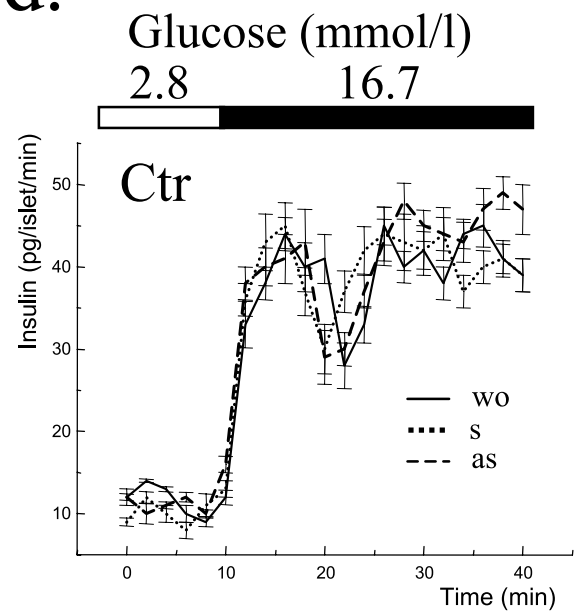

c.

Glucose $16.7 \mathrm{mmol} / 1$

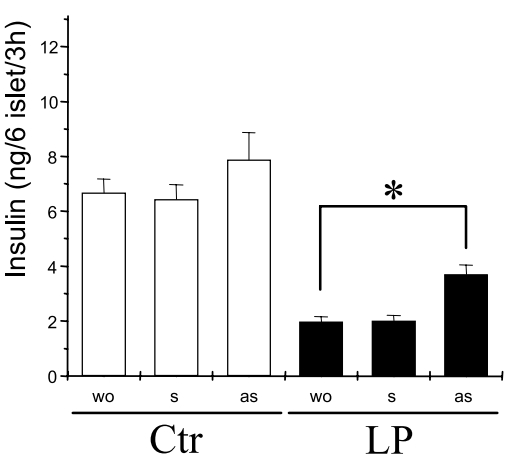

e.

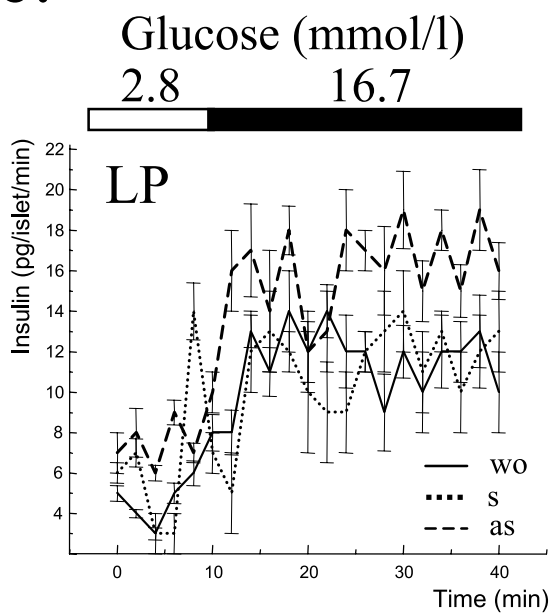

Figure 5 Effects of pancreatic islet IRS-2 protein expression reduction by IRS-2 phosphorthioate antisense oligonucleotide on static and dynamic insulin secretion by isolated pancreatic islets of control $(\mathrm{Ctr})$ and protein-deficient $(\mathrm{LP})$ rats. Total protein $(200 \mu \mathrm{g})$ from pancreatic islets of control and protein-deficient rats, treated with IRS-2 phosphorthioate antisense (as) or sense (s) oligonucleotide, or not exposed to oligonucleotide (wo), were separated by SDS-PAGE, transferred to nitrocellulose membrane and blotted with anti-IRS-2 antibody (a). Groups of six $(\mathrm{b}-\mathrm{c})$ or $100(\mathrm{~d}-\mathrm{e})$ islets isolated from control or protein-deficient rats and treated with IRS-2 phosphorthioate antisense, sense oligonucleotide, or not exposed to oligonucleotide, were submitted to a protocol for evaluation of static insulin secretion in low $(2.8 \mathrm{mM})$ (b) or high $(16.7 \mathrm{mM})$ (c) glucose concentration, or for evaluation of dynamic insulin secretion ( $d$, control; e, protein-deficient rats), according to the methods described in Materials and Methods. In all experiments $n=6$ and ${ }^{*} P<0.05$ vs wo within the experimental group. Values are means \pm S.E.M. 
a.

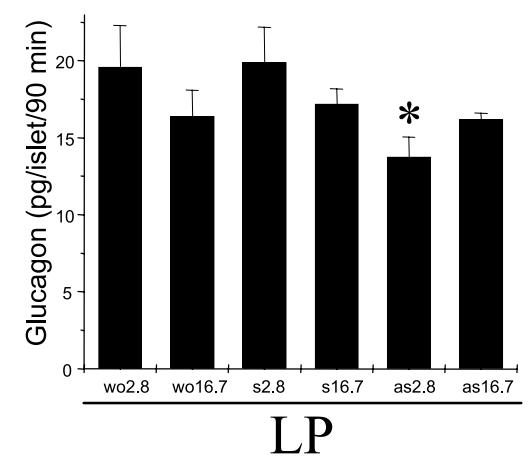

c.

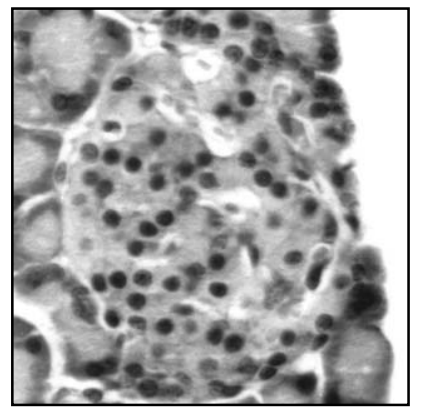

$10 \mu \mathrm{m}$ b.

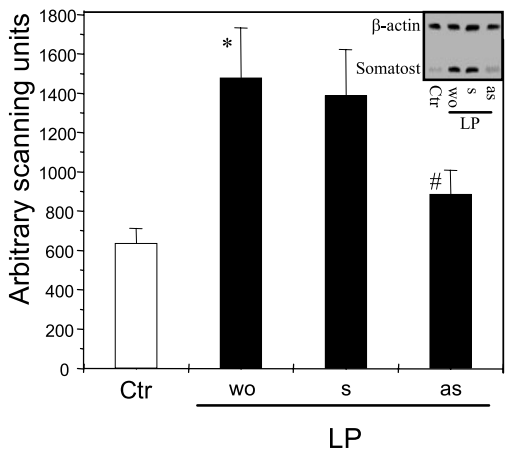

e.

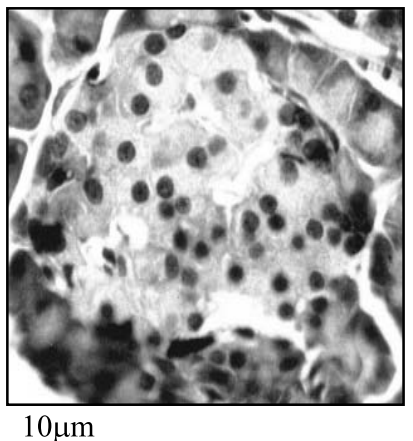

Figure 6 Effects of IRS-1 protein expression reduction by IRS-1 phosphorthioate antisense oligonucleotide on glucagon (a) secretion, and somatostatin (b-e) expression in pancreatic islets of control (Ctr) and protein-deficient (LP) rats. Groups of 100 islets isolated from protein-deficient rats and treated with IRS-1 phosphorthioate antisense (as) or sense (s) oligonucleotide, or not exposed to oligonucleotide (wo) were submitted to a protocol for evaluation of static glucagon secretion under low $(2.8 \mathrm{mM})$ or high $(16.7 \mathrm{mM})$ glucose concentration (a). Somatostatin (Somatost) mRNA expression was determined by RT-PCR (b) in pancreatic islets of control and protein-deficient rats treated with IRS-1 phosphorthioate antisense or sense oligonucleotide, or not exposed to oligonucleotide. mRNA quantification was performed in parallel with $\beta$-actin internal control. Immunohistochemical characterization of somatostatin expression in pancreatic islets of rats fed regular chow (d) and protein-deficient rats (e). Sections $(5 \mu \mathrm{m})$ of paraformaldehyde-fixed, paraffin-embedded pancreata of rats were stained using somatostatin primary antibodies and biotinylated secondary antibody followed by treatment with avidin coupled to peroxidase. Signal detection and image acquisition were performed with an optical microscope. In (a) $n=6$ and ${ }^{\star} P<0.05$ vs wo2.8. In (b) $n=6,{ }^{*} P<0.05$ vs $\mathrm{Ctr}$ and ${ }^{\#} P<0.05$ vs LP/wo. A methodological control for immunohistochemical characterization of somatostatin expression was obtained by exposing sections of pancreas from protein-deficient (c) and control (not shown) rats to species-specific pre-immune sera. In (c-e) photographs are representative of three distinct experiments.

Thus, another reason for studying insulin secretion in protein-deficient states is the fact that a full characterization of the mechanisms that lead to defective functioning of pancreatic $\beta$-cells may provide clues for understanding the pathways that contribute to impaired insulin secretion in the highly prevalent type 2 diabetes.

Several studies have attempted to characterize the molecular mechanisms underlying the impaired response of the pancreatic islets of protein-deficient animals to glucose and other insulinotrophic agents (Rao \& Menon
1993, Reis et al. 1997, Latorraca et al. 1998, Barbosa et al. 2002, Ferreira et al. 2003). Caloric and protein deficiency produce phenotypic changes in pancreatic islets, which are smaller and composed of a lower number of $\beta$-cells, than islets of eutrophic animals (Petrik et al. 2001). In addition, the remaining $\beta$-cells are less responsive to glucose, presenting a higher $K_{\mathrm{m}}$ and a lower maximum insulin secretion rate (Reis et al. 1997). In a recent study, Pende et al. (2000) showed that mice made deficient for S6 kinase 1 (S6K1) are hypoinsulinemic and glucose intolerant. 
Their pancreatic islets are considerably smaller than those of wild-type mice and, according to the authors, their islets resemble and function like pancreatic islets of proteindeficient mice. S6K1 is an effector of PI3-kinase and may integrate signals generated by hormones, growth factors and metabolites (Pende et al. 2000). This same intracellular signaling pathway is employed by insulin to exert autocrine control of its own transcription, acting through IR subtype A and engaging IRS proteins (Leibiger et al. 2001). Experiments with $\beta$-cell-specific IR knockout mice (Kulkarni et al. 1999a) and with IRS-1 (Araki et al. 1994) and IRS-2 (Withers et al. 1999) whole-body knockouts suggest that autocrine insulin signaling favors islet mass growth and stimulates insulin synthesis and secretion. However, previous physiological studies (Malaisse \& Malaisse-Lagae 1969) and recently published data (Araujo et al. 2002, Persaud et al. 2002) demonstrate that by acting upon undisrupted and non-genetically manipulated islets, insulin exerts a negative regulatory effect upon its own secretion, which apparently occurs through intra-islet paracrine signaling (Araujo et al. 2002). By partially and transitorily inhibiting IRS-1 expression in pancreatic islet of Wistar rats, we were able to promote an increase in the amount and rate of insulin secretion (Araujo et al. 2002). Since pancreatic islets of proteindeficient rats present a defective insulin secretion, and since abrogation of expression of elements that participate in insulin signaling may produce islets that are phenotypically similar to islets from protein-deficient rodents (Pende et al. 2000), we decided to evaluate initial and intermediary steps of the insulin-signaling pathway in undisrupted pancreatic islets from protein-deficient rats.

The present animal model matches all hormonal, biochemical and phenotypic characteristics of those reported in previously published studies (Latorraca et al. 1998, Prada et al. 2001). The pancreatic islets of protein-deficient rats are smaller and possess fewer insulin granules than islets from eutrophic rats (not shown). Nevertheless, IR, IRS-1 and IRS-2 are expressed in pancreatic islets with the same pattern and histological distribution to those observed in control rats, i.e. more strongly stained in cells of the periphery of the islets, suggesting higher expression in non-insulin-secreting cells. Although not an appropriate method for quantitative analysis, the immunostainings suggested that pancreatic islets from protein-deficient rats express higher levels of IR and IRS-2, and a lower level of IRS-1 than islets of control rats. These findings were further confirmed by immunoblot and RT-PCR.

The treatment of isolated pancreatic islets with exogenous insulin promoted higher IR, IRS- 1 and IRS-2 tyrosine phosphorylation and increased IRS-1/IRS-2associated PI3-kinase activity in pancreatic islets from protein-deficient rats compared with control rats. Thus, there is a direct relationship between the amounts of IR and IRS-2 and their molecular response to insulin. On the other hand, although IRS-1 expression is considerably lower in islets from protein-deficient rats, it responds with higher insulin-induced molecular signaling than islets of control rats. A similar finding was described in some animal models of insulin resistance and, apparently, the induction of tyrosine phosphorylation of substrates of the IR by insulin reflects more appropriately the activation of this particular pathway than the simple measurement of specific protein expression (Kahn \& Saad 1992, Bezerra et al. 2000, Bertelli et al. 2003). In exercise-trained rats, which present a better response to insulin action, a similar phenomenon was described and, according to the authors, the net functional result in this particular situation is the same, i.e. tyrosine phosphorylation of the IR and its substrates is a more appropriate parameter for evaluating the cellular action of insulin than the amount of proteins engaged by the signaling pathway (Chibalin et al. 2000). In conclusion, islets of protein-deficient rats express proteins that participate in insulin signaling with a similar tissue distribution to that observed in islets of eutrophic rats. Upon insulin stimulation, however, islets of proteindeficient rats respond with higher molecular activation of the IR/IRS-1, -2/PI3-kinase signaling pathway than islets of control rats.

The treatment of pancreatic islets of protein-deficient rats with IRS-1 antisense oligonucleotide promoted an $\sim 60 \%$ reduction in IRS-1 expression compared with islets of protein-deficient rats not treated with antisense oligonuclotide, and $\sim 85 \%$ reduction compared with islets of control rats not treated with antisense oligonucleotide. The treatment of pancreatic islets of control rats with IRS-1 antisense oligonucleotide also caused a considerable reduction in IRS-1 expression. In both cases (proteindeficient and control islets), the partial inhibition of IRS-1 expression led to a significant and sustained increase in glucose-induced insulin secretion. These phenomena were accompanied by a reversal of the pattern of glucoseregulated glucagon secretion and to an increase in somatostatin mRNA expression.

Since insulin is known to induce an increase in its own secretion in isolated $\beta$-cells (Kulkarni et al. 1999b, Leibiger et al. 2001), we believe that the effect of the inhibition of IRS-1 signaling, leading to an improvement, instead of impairment, of insulin secretion, is due to indirect mechanisms. In the present and a previous study (Araujo et al. 2002), we have demonstrated that the highest expression of proteins that participate in insulin signaling occurs in non-insulin-secreting cells, most specifically $\delta$-cells, but also in $\alpha$-cells. Moreover, islets from control and proteindeficient rats present an increased somatostatin expression accompanied by a reversal of the glucagon secretion pattern when treated with IRS-1 antisense oligonucleotide. This pattern of hormone secretion may participate in paracrine signaling and favor insulin secretion.

Finally, the possible reasons why protein deprivation promoted a reduction of IRS-1 accompanied by an increase of IRS-2 expression deserves some considerations. 
Since IRS-2 signaling in pancreatic islets seems to be predominantly related to growth promotion (Withers et al. 1999), we suspect that its induction may occur as an effort to stimulate pancreatic islet mass growth, which is impaired by the lack of nutrients. On the other hand, the pancreatic islet IRS-1 protein participates mostly in the control of insulin secretion, and its activation in undisrupted islets leads to inhibition of insulin secretion (Araki et al. 1994, Kulkarni et al. 1999b). Therefore, the reduction of IRS-1 expression in islets of protein-deficient rats may reflect an adaptation for improving insulin secretion in this insulinopenic animal model. The highest effect of IRS-1 protein synthesis reduction by oligonucleotide antisense treatment upon insulin secretion as compared with IRS-2 protein synthesis reduction provides further support for the specialized roles of each of these substrates for insulin (and possibly IGF-I) signaling in pancreatic islets.

In conclusion, a higher molecular response to exogenous insulin is detected in pancreatic islets of proteindeficient rats. The impairment of IRS-1 expression in isolated islets of protein-deficient rats partially restores the insulin secretion defect and modulates glucagon secretion and somatostatin expression. These data provide further support for a more robust role of paracrine, rather than autocrine, insulin signaling in pancreatic islets.

\section{Acknowledgements}

This work was supported by grants from Fundação de Amparo à Pesquisa do Estado de Sao Paulo (FAPESP) and Conselho Nacional de Pesquisa (PRONEX).

\section{References}

Abu-Bakare A, Taylor R, Gill GV \& Alberti KG 1986 Tropical or malnutrition-related diabetes: a real syndrome? Lancet $\mathbf{1 7}$ 1135-1138.

Araki E, Lipes MA, Patti ME, Bruning JC, Haag B 3rd, Johnson RS \& Kahn CR 1994 Alternative pathway of insulin signalling in mice with targeted disruption of the IRS-1 gene. Nature $\mathbf{3 7 2}$ 186-190.

Araujo EP, Amaral ME, Souza CT, Bordin S, Ferreira F, Saad MJ, Boschero AC, Magalhaes EC \& Velloso LA 2002 Blockade of IRS-1 in isolated rat pancreatic islets improves glucose-induced insulin secretion. FEBS Letters 531 437-442.

Aspinwall CA, Lakey JR \& Kennedy RT 1999 Insulin-stimulated insulin secretion in single pancreatic beta cells. Journal of Biological Chemistry 274 6360-6365.

Aspinwall CA, Qian WJ, Roper MG, Kulkarni RN, Kahn CR \& Kennedy RT 2000 Roles of insulin receptor substrate-1, phosphatidylinositol 3-kinase, and release of intracellular Ca2+ stores in insulin-stimulated insulin secretion in beta-cells. Journal of Biological Chemistry 275 22331-22338.

Barbosa FB, Capito K, Kofod H \& Thams P 2002 Pancreatic islet insulin secretion and metabolism in adult rats malnourished during neonatal life. British Journal of Nutrition 87 147-155.

Bell GI \& Polonsky KS 2001 Diabetes mellitus and genetically programmed defects in beta-cell function. Nature 414 788-791.
Bertelli DF, Ueno M, Amaral ME, Toyama MH, Carneiro EM, Marangoni S, Carvalho CR, Saad MJ, Velloso LA \& Boschero AC 2003 Reversal of denervation-induced insulin resistance by SHIP2 protein synthesis blockade. American Journal of Physiology, Endocrinology and Metabolism 284 E679-E687.

Bezerra RM, Ueno M, Silva MS, Tavares DQ, Carvalho CR \& Saad MJ 2000 A high fructose diet affects the early steps of insulin action in muscle and liver of rats. Journal of Nutrition 130 1531-1535.

Bjork E, Velloso LA, Kampe O \& Karlsson FA 1994 GAD autoantibodies in IDDM, stiff-man syndrome, and autoimmune polyendocrine syndrome type I recognize different epitopes. Diabetes 43 161-165.

Bradford MM 1976 A rapid and sensitive method for the quantitation of microgram quantities of protein utilizing the principle of protein-dye binding. Annals of Biochemistry 72 248-254.

Chibalin AV, Yu M, Ryder JW, Song XM, Galuska D, Krook A, Wallberg-Henriksson H \& Zierath JR 2000 Exercise-induced changes in expression and activity of proteins involved in insulin signal transduction in skeletal muscle: differential effects on insulin-receptor substrates 1 and 2. PNAS 97 38-43.

Ferreira F, Filiputti E, Arantes VC, Stoppiglia LF, Araujo EP, Delghingaro-Augusto V, Latorraca MQ, Toyama MH, Boschero AC \& Carneiro EM 2003 Decreased cholinergic stimulation of insulin secretion by islets from rats fed a low protein diet is associated with reduced protein kinase $\mathrm{c}$ alpha expression. Journal of Nutrition 133 695-699.

Hales CN 1997 Non-insulin-dependent diabetes mellitus. British Medical Bulletin 53 109-122.

Hales CN \& Barker DJ 2001 The thrifty phenotype hypothesis. British Medical Bulletin 60 5-20.

Kahn CR \& Saad MJ 1992 Alterations in insulin receptor and substrate phosphorylation in hypertensive rats. Journal of the American Society of Nephrology 3 S69-S77.

Kubota N, Tobe K, Terauchi Y, Eto K, Yamauchi T, Suzuki R, Tsubamoto Y, Komeda K, Nakano R, Miki H, Satoh S, Sekihara H, Sciacchitano S, Lesniak M, Aizawa S, Nagai R, Kimura S, Akanuma Y, Taylor SI \& Kadowaki T 2000 Disruption of insulin receptor substrate 2 causes type 2 diabetes because of liver insulin resistance and lack of compensatory beta-cell hyperplasia. Diabetes 49 1880-1889.

Kulkarni RN, Bruning JC, Winnay JN, Postic C, Magnuson MA \& Kahn CR 1999a Tissue-specific knockout of the insulin receptor in pancreatic beta cells creates an insulin secretory defect similar to that in type 2 diabetes. Cell 96 329-339.

Kulkarni RN, Winnay JN, Daniels M, Bruning JC, Flier SN, Hanahan D \& Kahn CR 19996 Altered function of insulin receptor substrate-1-deficient mouse islets and cultured beta-cell lines. Journal of Clinical Investigation 104 R69-R75.

Latorraca MQ, Reis MA, Carneiro EM, Mello MA, Velloso LA, Saad MJ \& Boschero AC 1998 Protein deficiency and nutritional recovery modulate insulin secretion and the early steps of insulin action in rats. Journal of Nutrition 128 1643-1649.

Leibiger B, Leibiger IB, Moede T, Kemper S, Kulkarni RN, Kahn CR, de Vargas LM \& Berggren PO 2001 Selective insulin signaling through $\mathrm{A}$ and $\mathrm{B}$ insulin receptors regulates transcription of insulin and glucokinase genes in pancreatic beta cells. Molecular Cell 7 559-570.

Lingohr MK, Dickson LM, McCuaig JF, Hugl SR, Twardzik DR \& Rhodes CJ 2002 Activation of IRS-2-mediated signal transduction by IGF-1, but not TGF-alpha or EGF, augments pancreatic beta-cell proliferation. Diabetes $\mathbf{5 1}$ 966-976.

Luciano E, Carneiro EM, Carvalho CR, Carvalheira JB, Peres SB, Reis MA, Saad MJ, Boschero AC \& Velloso LA 2002 Endurance training improves responsiveness to insulin and modulates insulin signal transduction through the phosphatidylinositol 3-kinase/Akt-1 pathway. European Journal of Endocrinology 147 149-157.

Malaisse W \& Malaisse-Lagae F 1969 Chronic effects of insulin and glucagon upon islet function. Diabetologia 5 349-352. 
Pende M, Kozma SC, Jaquet M, Oorschot V, Burcelin R, Le Marchand-Brustel Y, Klumperman J, Thorens B \& Thomas G 2000 Hypoinsulinaemia, glucose intolerance and diminished beta-cell size in S6K1-deficient mice. Nature 408 994-997.

Persaud SJ, Asare-Anane H \& Jones PM 2002 Insulin receptor activation inhibits insulin secretion from human islets of Langerhans. FEBS Letters $\mathbf{5 1 0}$ 225-228.

Petrik J, Srinivasan M, Aalinkeel R, Coukell S, Arany E, Patel MS \& Hill DJ 2001 A long-term high-carbohydrate diet causes an altered ontogeny of pancreatic islets of Langerhans in the neonatal rat. Pediatric Research 49 84-92.

Prada FJ, Luciano E, Carneiro EM, Boschero AC \& Mello MA 2001 Protein deficiency attenuates the effects of alloxan on insulin secretion and glucose homeostasis in rats. Physiological Chemistry and Physics and Medical NMR 33 73-82.

Rao RH 1988 Diabetes in the undernourished: coincidence or consequence? Endocrine Reviews 9 67-87.

Rao RH \& Menon RK 1993 Chronic malnutrition impairs insulin sensitivity through both receptor and postreceptor defects in rats with mild streptozocin diabetes. Metabolism 42 772-779.

Reeves PG, Nielsen FH \& Fahey GC Jr 1993 AIN-93 purified diets for laboratory rodents: final report of the American Institute of Nutrition ad hoc writing committee on the reformulation of the AIN-76A rodent diet. Journal of Nutrition 123 1939-1951.

Reis MA, Carneiro EM, Mello MA, Boschero AC, Saad MJ \& Velloso LA 1997 Glucose-induced insulin secretion is impaired and insulin-induced phosphorylation of the insulin receptor and insulin receptor substrate-1 are increased in protein-deficient rats. Journal of Nutrition 127 403-410.

Saltiel AR \& Kahn CR 2001 Insulin signalling and the regulation of glucose and lipid metabolism. Nature 414 799-806.
Velloso LA, Carneiro EM, Crepaldi SC, Boschero AC \& Saad MJ 1995 Glucose- and insulin-induced phosphorylation of the insulin receptor and its primary substrates IRS-1 and IRS-2 in rat pancreatic islets. FEBS Letters 377 353-357.

Velloso LA, Folli F, Sun XJ, White MF, Saad MJ \& Kahn CR 1996 Cross-talk between the insulin and angiotensin signaling systems. PNAS 93 12490-12495.

Withers DJ, Gutierrez JS, Towery H, Burks DJ, Ren JM, Previs S, Zhang Y, Bernal D, Pons S, Shulman GI, Bonner-Weir S \& White MF 1998 Disruption of IRS-2 causes type 2 diabetes in mice. Nature 391 900-904.

Withers DJ, Burks DJ, Towery HH, Altamuro SL, Flint CL \& White MF 1999 Irs-2 coordinates Igf-1 receptor-mediated beta-cell development and peripheral insulin signalling. Nature Genetics 23 $32-40$.

Xu GG, Gao ZY, Borge PD Jr \& Wolf BA 1999 Insulin receptor substrate 1-induced inhibition of endoplasmic reticulum $\mathrm{Ca}^{2+}$ uptake in beta-cells. Autocrine regulation of intracellular $\mathrm{Ca}^{2+}$ homeostasis and insulin secretion. Journal of Biological Chemistry 274 18067-18074.

Zhang Q, Berggren PO, Hansson A \& Tally M 1998 Insulin-like growth factor-I-induced DNA synthesis in insulin-secreting cell line RINm5F is associated with phosphorylation of the insulin-like growth factor-I receptor and the insulin receptor substrate-2. Journal of Endocrinology 156 573-581.

Zimmet P, Alberti KG \& Shaw J 2001 Global and societal implications of the diabetes epidemic. Nature 414 782-787.

Received in final form 4 December 2003 Accepted 11 December 2003 